\title{
DARI FULL DAY SCHOOL KE KEBIJAKAN ENAM HARI SEKOLAH: RASIONALISASI PRAKTIK DAN EVALUASI PEMBELAJARAN PASCA FULL DAY SCHOOL DI SMA NEGERI 1 KEDUNGREJA KABUPATEN CILACAP
}

\author{
Apriyani, Nurul Fatimah, Harto Wicaksono \\ Universitas Negeri Semarang \\ Email:apriyani467@gmail.com,fatimahnurul18@mail.unnes.ac.id,hartowicaksono@mail.unnes.ac.id
}

\begin{abstract}
Abstrak Tujuan penelitian ini adalah mengetahui bagaimana praktik dan evaluasi pembelajaran pasca Full Day School (FDS) di SMA Negeri 1 Kedungreja pasca praktik FDS. Penelitian dilaksanakan di SMA Negeri 1 Kedungreja dengan pendekatan kualitatif. Adapun fokus penelitiannya, yaitu rasionalitas kebijakan kembali enam hari sekolah, praktik pembelajaran pasca FDS, dan tanggapan guru, orangtua, dan peserta didik terhadap diberlakukannya kebiajkan enam hari sekolah. Teknik pengumpulan data dilaksanakan melalui observasi partisipan, wawancara, dan dokumentasi. Data penelitian dianalisis dengan teknik analisis deskriptif kualitatif. Hasil penelitian menunjukan bahwa (1) alasan SMA Negeri 1 Kedungreja kembali pada kebijakan enam hari sekolah pasca full day school karena dalam pelaksanaan full day school sekolah mengalami kendala yang berdampak pada kualitas pembelajaran, baik pada aspek proses maupun hasil. (2) Proses pelaksanaan pembelajaran dalam sekolah enam hari pasca full day school di SMA Negeri 1 Kedungreja tidak jauh berbeda dengan pembelajaran ketika full day school baik dilihat dari model dan metode yang digunakan. (3) Guru, peserta didik, dan orang tua peserta didik memberikan tanggapan yang beragam terkait pelaksanaan sekolah enam hari pasca full day school, baik pro dan kontra sesuai dengan kebutuhannya masing-masing.

Kata kunci: $\quad$ Kebijakan, Full Day School, Sekolah Enam Hari
\end{abstract}

\section{PENDAHULUAN}

Pemerintah Indonesia telah melakukan berbagai upaya untuk meningkatkan kualitas pendidikan formal di Indonesia. Hal demikian harus dilakukan agar outcome pendidikan dapat berdaya saing global, namun tetap tidak meninggalkan nilai dan pendidikan karakter yang selama ini banyak dikembangkan. Upaya untuk meningkatkan Sumberdaya Daya Manusia (SDM) mulai dari meningkatkan kualitas bagi tenaga pendidik, penyediaan sarana dan prasarana sekolah yang berkualitas, sampai mengubah kurikulum dalam penyelenggaraan pendidikan di sekolah. Beberapa upaya tersebut bahkan menjadi kebijakan nasional yang mau tidak mau, sekolah wajib mengikutinya. Mulai dari perencanaan, proses, sampai hasil dan evaluasi menjadi fokus sekolah untuk dapat menyesuaikan kebijakan pemerintah. Salah satu kebijakan yang sempat menjadi perbincangan dan menarik untuk dikaji adalah kebijakan mengenai Full Day School (FDS) yang tertuang dalam permendikbud tahu 2017, nomor 23 mengenai hari sekolah.

FDS berasal dari Bahasa Inggris yang memiliki arti sekolah sehari penuh, namun istilah tersebut tidak berarti peserta didik berada di sekolah selama 24 jam. Peserta didik berada di sekolah dari pukul 07.00 WIB hingga pukul 16.00 WIB, dengan durasi istirahat setiap dua jam sekali. Jadi peserta didik berada di sekolah selama 9 jam. Lama waktu peserta didik di sekolah dengan sistem FDS lebih panjang 3 jam dari peserta didik yang bersekolah dengan sistem half day school. Oleh karena itu, sekolah dapat mengatur jadwal pelajaran secara leluasa yang disesuaikan dengan bobot mata pelajaran yang ditambah dengan pendalaman materi.

FDS sendiri diadopsi dari pendidikan yang ada di Amerika. Alasannya banyaknya ibu di Amerika Serikat yang memiliki pekerjaan di luar rumah tangga menginginkan anaknya memiliki prestasi akademik yang lebih baik serta peserta didik dapat terhindar dari hal-hal yang negatif jika berada di luar sekolah. Sementara kebijakan FDS di Indonesia dilatarbelakangi kurangnya waktu peserta didik untuk menjalin kedekatan dengan keluarga. Ketika akhir pekan peserta didik diharapkan memiliki waktu yang lebih banyak untuk bersama keluarganya, sehingga kedekatan antara anak dan orang tua terjalin dengan baik. Ada beberapa alasan mengapa FDS banyak 
bermunculan. Pertama, kurang baiknya lingkungan masyarakat. Hal ini menuntut orang tua harus selalu megawasi anak-anaknya karena dikahawatirkan anak akan ikut dalam pergaulan atau lingkungan sosial yang kurang baik. Kedua, kurang adanya waktu yang disediakan orang tua untuk menemani anaknya dikarenakan adanya tuntutan pekerjaan, sosial atau apapun yang menyibukkan orang tua. Ketiga, kecenderungan anak apabila di rumah hanya bermain dan malas untuk belajar (Arsyadana, 2010).

Praktik sistem FDS di Indonesia sebenarnya sudah berjalan sebelum adanya kebijakan dari Kemendikbud, yaitu pada sekolah swasta dan sekolah internasional yang mengharuskan peserta didiknya untuk tinggal di asrama dan sekolah yang berbasis keagamaan seperti pesantren. Sejak disahkannya kebijakan Kemendikbud tentang FDS, sekolah negeri pun mulai mengimplementasikan sistem tersebut yang dipadukan dengan kurikulum di sekolah masingmasing.

Dalam kesehariannya, pelaksanaan FDS juga disebut dengan Sekolah Lima Hari (SLH) (Sofanudin, 2017). Dari isu FDS sampai penerapannya, kebijakan ini menjadi problematika sendiri baik bagi penyelenggara pendidikan maupun orangtua peserta didik. Munculnya kebijakan FDS memunculkan pro dan kontra. Munculnya pro dan kontra diikuti dengan berbagai respon, bagi yang pro berargumentasi untuk meningkatkan kualitas pendidikan. Sementara yang kontra beranggapan bahwa keberadaan FDS akan menggerus pendidikan nonformal keagamaan seperti TPQ. Respon tersebut muncul karena terjadi pemadatan sekolah dari enam hari menjadi 5 hari dengan konsekuensi jam pulang sekolah peserta didik menjadi sore, anak lelah, dan tidak bisa mengikuti pendidikan nonformal pada masyarakat dengan baik.

Kondisi di atas juga terjadi pada masyarakat Jawa Tengah, khususnya setelah adanya himbauan dari Gubernur JawaTengah dengan adanya surat edaran Nomor 420/006752/2015 tentang penyelenggaraan kegiatan pendidikan lima hari di Provinsi Jawa Tengah. Gubernur Jawa Tengah menghendaki untuk pendidikan menengah atas, terutama yang berstatus negeri untuk mengikuti kebijakan pusat mengenai penyelenggaraan FDS di sekolah. Dalam hal ini termasuk Sekolah Menengah Atas Negeri 1 Kedungreja tanpa kecuali, walaupun dalam praktiknya sekolah ini kembali kepada kebijakan lama, yaitu kembali pada kebijakan pendidikan enam hari sekolah.

Sekolah Menengah Atas Negeri 1 Kedungreja merupakan salah satu sekolah negeri di Kabupaten Cilacap yang pernah mengimplementasikan kebijakan FDS. SMA
Negeri 1 Kedungreja berdiri pada tahun 1996. SMA Negeri 1 Kedungreja bukanlah satu-satunya sekolah yang menerapkan kebijakan FDS. Kebijakan ini berjalan bersamaan dengan sekolah Negeri lainnya di Kabupaten Cilacap yang siap dengan program FDS.

Pada proses Full day school di SMA Negeri 1 Kedungreja, banyak kendala yang dihadapi guru dan peserta didik ketika pembelajaran di kelas. Pada saat jam pelajaran ke enam hingga selesai, peserta didik sudah tidak bisa fokus dengan materi yang disampaikan oleh guru, sehingga kelas menjadi tidak kondusif dan banyak peserta didik yang tidak bisa mengikuti pelajaran dengan baik.

Pada awal tahun ajaran 2016/2017 SMA Negeri 1 Kedungreja resmi kembali pada kebijakan sekolah enam hari yang sebelumnya sudah melalui rapat evaluasi menyangkut kebijakan FDS yang telah berjalan selama dua semester. Dalam evaluasi yang dilakukan oleh kepala sekolah, komite, dewan guru, dan wali murid, hasilnya kebijakan FDS tidak berjalan secara efektif dan berimbas pada berbagai aspek. Sehingga melalui berbagai pertimbangan, sekolah mengambil keputusan untuk menghentikan full day school dan kembali pada sekolah enam hari.

Penelitian tentang FDS telah banyak dilakukan seperti penelitian yang dilakukan oleh Refliandra (2014) tentang Perbedaan Tingkat Stres antara Peserta didik Sekolah Dasar yang Bersistem Full Day dan Half Day di beberapa SD yang menerapkan sistem full day school dan half day school di Yogyakarta. Hasil penelitian menunjukkan bahwa tingkat stres peserta didik SD full-day 82,90 persen lebih tinggi daripada peserta didik SD half-day yaitu 43,93 persen. Dari hasil kategorisasi, peserta didik SD full-day berada pada tingkat stres yang sedang, sedangkan peserta didik SD half-day berada pada tingkat stres yang rendah. Hal ini disebabkan karena peserta didik di sekolah full-day mendapatkan beban tugas yang lebih berat, waktu belajar di sekolah yang lebih panjang daripada peserta didik di sekolah half-day. Hal ini juga ada kesesuain dengan penelitian yang dilakukan oleh Wulandari, dkk (2018) yang membahas tentang analisis implementasi kebijakan FDS. Apa yang dibahas oleh Refliandra dan Wulandari merupakan evaluasi terhadap pelaksanaan FDS yang dilakukan di sekolah, sementara apa yang dilakukan oleh penulis adalah melihat kembalinya sekolah dari kebijakan FDS ke kebijakan enam hari. Apa yang belum dilaksanakan oleh peneliti sebelumnya, dikaji oleh penulis dalam rangka melengkapi kajian tentang FDS, baik dari aspek pelaksanaan kebijakan FDS maupun impact FDS sehingga sekolah kembali pada kebijakan yang lama. 
Studi lain dilakukan oleh Holm (2014) tentang Parental perspectives on Danish full-day schools for ethnicminority students. Hasilnya menunjukkan bahwa penerapan program full day school untuk etnik minoritas Danish di Vollmosh mengalami konflik dan pertentangan antara pihak orang tua dengan pihak sekolah. Beberapa orang tua khawatir dengan percobaan sekolah sehari penuh didasarkan pada anak-anak di Vollsmose yang "tidak pada tingkat yang sesuai dengan usia", karena alasan inilah yang mengharuskan orangtua untuk mentransfer anak-anak mereka ke sekolah lain yang tidak menjalankan program sekolah sehari penuh. Hari yang panjang di sekolah membatasi anak untuk merencanakan kegiatan mereka di waktu yang luang. Baik kami (penulis) maupun Holm melihat kendala dalam penyelenggaraan FDS, namun Holm memfokuskan pada tindakan orangtua yang memindahkan anaknya ke sekolah yang tidak menerapkan FDS. Sementara kami memfokuskan pada kebijakan intern sekolah yang melihat kurang efektifnya penyelenggaraan FDS, sehingga berdasarkan keputusan bersama pihak sekolah, komite, dan orangtua peserta didik sepakat pada kembalinya ke kebijakan enam hari sekolah.

Perspektif lain dalam mengkaji FDS dilakukan oleh Arioka. Arioka (2018) melihat FDS sebagai sebuah kebijakan dengan pendekatan teori kritis. Konsekuensinya, dasar lahirnya FDS ditempatkan sebuah ideologi yang pro terhadap kapitalis. Menurutnya Di tataran hubungan kuasa (power/proxy power) hasil penelitiannya menyatakan bahwa adannya hegemoni ideologi kapitalistik dalam penerapan FDS. Ideologi ini kemudian dilegitimasi lewat otoritas pengambil kebijakan, yakni Mendikbud (yang mendapatkan dukungan dari Presiden dan Wakil Presiden. Hal ini berbeda dengan kami yang melihat FDS sebagai sebuah kebijakan yang ketika diterapkan tidak banyak menguntungkan peserta didik dan penyelenggara pendidikan yang terkait, sehingga sekolah penyelenggara memberikan respon untuk kembali pada kebijakan enam hari sekolah. Penelitian ini menyempurnakan berbagai kendala yang diterapkan oleh sekolah dalam menerapkan FDS dengan berani mengambil sikap positif dan berbeda dari himbauan dan kebijakan, tetapi tidak mengesampingkan kualitas pendidikan sekolah. Kebijakan lokal dan tanggungjawab intern sekolah menjadi daya tarik untuk dilakukan penelitian yang belum banyak dikaji oleh peneliti terdahulu.

Dalam membahas topik FDS, maka kami menggunakan beberapa teori, yaitu (1) teori evalasi program model Context, Input, Process, Product, Output oleh Stufflebeam yang dikembangkan Arikunto tahun 2000. Evaluasi program adalah upaya penyediaan informasi untuk disampaikan kepada pengambil keputusan (Arikunto dan Cepi Safrudin, 2014: 5). Evaluasi program dapat dilakukuan di berbagai bidang salah satunya adalah program pendidikan. Evaluasi program dalam bidang pendidikan merupakan suatu kegiatan terencana yang bertujuan untuk mengetahui tercapainya program pendidikan. Model yang digunakan oleh peneliti dalam penelitian ini adalah evaluasi model CIPP (Context, Input, Process, Product). (2) Teori difusi inovasi dalam pendidikan oleh Evrett Roger. Teori difusi inovasi menurut Roger adalah bagaimana suatu difusi disampaikan melalui saluran-saluran tertentu sepanjang waktu kepada sekolompok anggota dari sistem sosial. Terdapat empat elemen pokok dalam difusi inovasi menurut pemikiran Roger (dalam Yusuf, 2013): (a) Inovasi merupakan gagasan tindakan atau barang yang dianggap baru oleh seseorang, (b) Saluran komunikasi merupakan alat untuk menyampaikan pesan-pesan inovasi dari sumber kepada penerimanya, (c) Jangka waktu dalam proses pengambilan keputusan untuk menerima atau menolak inovasi, (d) Sistem sosial yang merupakan kumpulan unit yang berbeda secara fungsional dan terkait kerjasama untuk memecahkan masalah dalam rangka mencapai tujuan bersama. Tulisan ini bertujuan untuk; (1) mengetahui alasan sekolah mengambil keputusan untuk kembali ke kebijakan enam hari sekolah pascakebijakan full day school di SMA Negeri 1 Kedungreja, (2) mengetahui proses pelaksanaan sekolah enam hari dalam kegiatan pembelajaran di kelas pasca full day school di SMA Negeri 1 Kedungreja, (3) mengetahui tanggapan dari peserta didik dan orang tua peserta didik atas diberlakukannya kembali kebijakan enam hari sekolah di SMA Negeri 1 Kedungreja.

\section{METODE PENELITIAN}

Penelitian ini menggunakan metode kualitatif. Metode kualitatif digunakan untuk mendapatkan data yang mendalam, suatu data yang mengandung makna dan tidak menekankan pada generalisasi (Sugiyono, 2013). Fokus kajian dalam penelitian ini terletak pada dampak sekolah enam hari pasca full day school dalam pembelajaran di SMA Negeri 1 Kedungreja yang berkonsekuensi pada kembalinya penerapan kebijakan enam hari sekolah. Lokasi penelitian ini adalah SMA Negeri 1 Kedungreja Kabupaten Cilacap dengan alasan SMA Negeri 1 Kedungreja merupakan satu-satunya sekolah yang berstatus negeri di wilayah Kabupaten Cilacap bagian Barat yang menghentikan program full day school dan kembali pada kebijakan sekolah enam hari. 
Informan utama dalam penelitian ini adalah guru, peserta didik, dan waka kurikulum, sedangkan informan pendukung dalam penelitian ini adalah orang tua peserta didik. Teknik pengumpulan data yang digunakan yaitu wawancara, observasi, dan dokumentasi. Keabsahan data menggunakan triangulasi data. Teknik analisis data meliputi pengumpulan data, reduksi data, penyajian data, dan penarikan kesimpulan atau verifikasi.

\section{HASIL DAN PEMBAHASAN}

Penelitian ini dilaksanakan pada 17 Maret s/d 8 April 2017 di SMA Ngeri 1 Kedungreja yang terletak di Jalan Raya Tambaksari Tromol Pos 212 Kecamatan Kedungreja Kabupaten Cilacap. SMA Negeri 1 Kedungreja memiliki berbagai prestasi di bidang akademik dan non akademik. Berbagai kejuaraan di raih Sekolah, berdasarkan hasil observasi yang dilakukan oleh penulis SMA Negeri 1 Kedungreja memiliki berbagai kejuaraan yang pernah diraih sekolah pada tahun 2016 dan 2017 diantaranya juara II OSN tingkat kabupaten pada tahun 2016, juara II lomba FLS2N tingkat Kabupaten pada tahun 2016, Juara III lomba Seni Kriya tingkat Kabupaten tahun 2017, Juara II Lomba Baca puisi tingkat kabupaten tahun 2017, dan juara I lomba tilawatil Qur'an tingkat Kabupaten. SMA Negeri 1 Kedungreja memiliki visi yaitu "Prestasi Unggul Bermartabat" untuk mencapai visi tersebut melalui misi yang ada. Berikut adalah misi SMA Negeri 1 Kedungreja; Pertama, melaksanakan kurikulum tingkat satuan pendidikan. Kedua, menyediakan sarana pendidikan pendukung kegiatan belajar mengajar. Ketiga, mewujudkan pendidikan yang menghasilkan lulusan berkualitas, beriman dan berkompetensi. Keempat, menumbuhkan minat belajar peserta didik secara optimal. Kurikulum merupakan salah satu alat untuk mencapai tujuan sekolah. Kurikulum yang diterapkan di SMA Negeri 1 Kedungreja adalah KTSP dan Kurikulum 2013. Sekolah mulai menerapkan kurikulum 2013 di kelas X sedangkan KTSP masih diterapkan di kelas XI dan kelas XII. Hal ini karena sekolah memiliki alasan dan bahan pertimbangan mengapa tidak mengganti kurikulum 2013 secara keseluruhan.

SMA Negeri 1 Kedungreja memiliki ruang kelas sebanyak 20 ruang yang digunakan untuk belajar mengajar, dengan rincian sebagai berikut Kelas X memiliki 4 kelas untuk program MIA dan 2 kelas untuk program IIS, kelas XI dan XI memiliki 4 kelas untuk program MIA dan 3 Kelas Untuk program IIS. SMA Negeri 1 Kedungreja memiliki jumlah Guru sebanyak 39 orang dengan rincian jumlah guru laki-laki sebanyak 23 orang dan Perempuan sebanyak 16 orang dengan keadaan guru PNS dan Wiyata Bhakti. Sebagian besar guru yang ada di sekolah berasal dari daerah sekitar Kecamatan Kedungreja dan Kecamatan Sidareja.

\section{Praktik Full Day School di SMA Negeri 1 Kedungreja}

Pelaksanaan full day school di SMA Negeri 1 Kedungreja dijalankan berdasarkan surat edaran dari Gubernur Jawa Tengah Nomor 420/006752/2015 tentang penyelenggaraan kegiatan pendidikan di Provinsi Jawa. Dalam surat edaran tersebut tertuang perintah untuk menyelenggarakan pendidikan lima hari per minggu. Berdasarkan surat edaran tersebut, maka pada awal tahun ajaran 2015/2016 SMA Negeri 1 Kedungreja resmi menjalankan pendidikan lima hari per minggu. Dilihat dari kesiapan sekolah dalam penyelenggaraan pendidikan lima hari per mingu, sebenarnya sekolah belum siap dengan program tersebut. Sekolah belum benar-benar siap untuk menyelenggarakan program full day school karena banyak hal yang harus dipersiapkan mulai dari sarana prasarana, kesiapan guru, kesiapan peserta didik, dan assessment lainnya. Meskipun kebijakan tersebut berlaku bagi sekolah yang sudah siap dengan program penyelenggaraan pendidikan lima hari per minggu, SMA Negeri 1 Kedungreja tetap menjalankan program tersebut serentak dengan sekolah menengah atas lain yang ada di Kabupaten Cilacap bagian Barat seperti SMA Negeri 1 Sidareja, SMA Negeri 1 Patimuan, SMA Negeri 1 Majenang, SMA Negeri 1 Bantarsari, dan SMA Negeri 1 Cipari.

Dalam praktiknya full day school di SMA Negeri 1 Kedungreja, sekolah mengatur ulang jadwal yang sudah berjalan sebelumnya yaitu ketika sekolah enam hari. Adapun perubahan jadwal kegiatan belajar mengajar di SMA Negeri 1 Kedungreja ketika full day school sebagai berikut setiap hari senin sampai jumat sekolah masuk pukul 07.00 dan pulang pukul 16.00, sedangkan waktu istirahat yaitu istirahat pertama jam 10.00 sampai dengan jam 10.15 dan istirahat kedua jam 11.45 sampai jam 12.30 waktu untuk istirahat kedua sekolah membuatnya lebih panjang karena peserta didik harus makan siang dan melaksanakan ibadah sholat dzuhur begitu pun dengan guru. Setiap hari terdapat sepuluh jam pelajaran yang berisis lima hingga enam mata pelajaran. Sekolah memiliki estimasi waktu pelajaran 45 menit untuk setiap satu jamnya. Sementara itu, kegiatan lain yang termasuk di dalamnya adalah kegiatan ekstrakulikuler selain pramuka dilaksanakan setiap hari selasa. 


\section{Rasionalitas SMA Negeri 1 Kedungreja Kembali pada Kebijakan Enam Hari Sekolah}

Pelaksanaan full day school di SMA Negeri 1 Kedungreja hanya dapat berjalan selama dua semester. Pada awal tahun ajaran 2016/2017 sekolah memutuskan untuk menghentikan full day school dan kembali pada kebijakan lama, yaitu sekolah enam hari karena dalam pelaksanaan full day school banyak kendala yang dihadapi oleh sekolah. Melalui rapat pleno yang diselenggrakan sekolah dengan melibatkan kepala sekolah, dewan guru dan komite sekolah, membahas tentang evaluasi pelaksanaan program full day school yang telah berjalan, hasilnya banyak kendala yang dihadapi sekolah terutama pada guru dan peserta didik ketika pembelajaran dengan sistem full day school. Selain melibatkan kepala sekolah, komite dan dewan guru, sebelumnya sekolah telah memberikan surat kepada orang tua peserta didik untuk memilih anaknya sekolah lima hari atau enam hari. Hasilnya sebanyak $75 \%$ orang tua peserta didik memilih anaknya sekolah enam hari. Hal ini dijadikan sebagai salah satu pertimbangan sekolah dalam rapat evaluasi program full day school.

Roger (1983) mendefinisikan sistem sosial sebagai suatu kumpulan unit yang berbeda secara fungsional dan saling terikat dalam kerjasama untuk memecahkan masalah dalam rnagka mencapai tujuan. Di antara anggota sistem sosial ada yang memegang peranan penting dalam proses difusi, yakni mereka yang disebut degan pemuka pendapat. Pemuka pendapat merupakan orang yang memengaruhi sikap dan tingkah laku orang lain. Pemuka pendapat memiliki pengaruh terhadap proses penyebaran inovasi. Kepala Sekolah merupakan seseorang yang memiliki pengaruh besar di sekolah terkait kebijakan salah satunya full day school. Dalam pengambilan keputusan SMA Negeri 1 Kedungreja menggunakan tipe keputusan inovasi opsional yaitu pemilihan menerima atau menolak inovasi berdasarkan keputusan yang ditentukan oleh individu yang dalam hal ini keputusan di ambil oleh Kepala SMA Negeri 1 Kedungreja. Ada beberapa bahan pertimbangan sekolah dalam mengambil keputusan untuk menghentikan full day school dan kembali pada kebijakan sekolah enam hari di antaranya; aspek psikologis, apek sarana dan prasarana, aspek guru dan peserta didik, aspek nilai akademik peserta didik dan aspek kondisi sosial enonomi peserta didik.

Komponen variabel evaluasi program full day school ialah Product (Hasil). Komponen Hasil adalah sesuatu yang didapat oleh peserta didik dan guru yang berupa pencapaian tujuan program full day school. Komponen hasil dapat berupa pembelajaran yang diperoleh guru dan peserta didik. Program full day school yang telah diterapkan di SMA Negeri 1 Kedungreja, hasilnya terdapat penurunan pada prestasi akademik peserta didik, kelelahan yang dirasakan oleh guru dan peserta didik pada saat pembelajaran dan kurangnya waktu bagi guru dan peserta didik untuk berkumpul bersama dengan keluarga berpengaru terhadap kualitas hasil akademik.

\section{Proses dan Evaluasi Pembelajaran Pasca Full Day School}

Secara prosedur, tidak ada perubahan dalam proses pembelajaran antara sekolah lima hari dan sekolah enam hari. Pembelajaran pada sekolah enam hari tidak jauh berbeda dengan pembelajaran ketika sekolah lima hari baik dari model dan metode yang digunakan. Hanya saja pembelajaran pada sekolah lima hari lebih membutuhkan banyak variasi dalam pembelajaran guna mengatasi kejenuhan peserta didik, sedangkan pada sekolah enam hari pembelajaran dilakukan dengan monoton.

Kelas XI di SMA Negeri 1 Kedungreja sampai saat ini masih menerapkan Kurikulum Tingkat Satuan Pendidikan. Hal ini akan mempengaruhi bagaimana proses pembelajaran di kelas. Penulis memilih kelas XI IIS 2 sebagai kelas contoh dalam penelitian karena kelas tersebut adalah kelas yang tergolong tidak aktif. Materi yang dibahas adalah masyarakat multikultural. Pembelajaran dilakukan pada jam ke lima dan jam ke enam yaitu tepatnya pukul 09.45 sampai dengan pukul 11.45. Dalam materi masyarakat multikultural terdapat nilai karakter yang akan ditanamkan Guru kepada kepada peserta didik. Nilai nilai yang tertanam kepada peserta didik dalam materi masyarakat multikultural yaitu sikap toleransi, rasa ingin tahu, cinta kebangsaan akan adanyanya masyarakat yang multikultural, sikap peduli dengan lingkungan sekitar dan memiliki sikap tanggung jawab.

Sebelum melaksanakan pembelajaran Sosiologi di Kelas XI IIS 2, Bapak Novrianto (guru) memasuki ruang kelas dan melakukan apersepsi berupa pembacaan Asmaul Husna bersama-sama dan dilanjutkan dengan membaca doa. SMA Negeri 1 Kedungreja sudah membiasakan peserta didiknya untuk membaca Asmaul Husna sebelum pelajaran sejak delapan tahun yang lalu. 


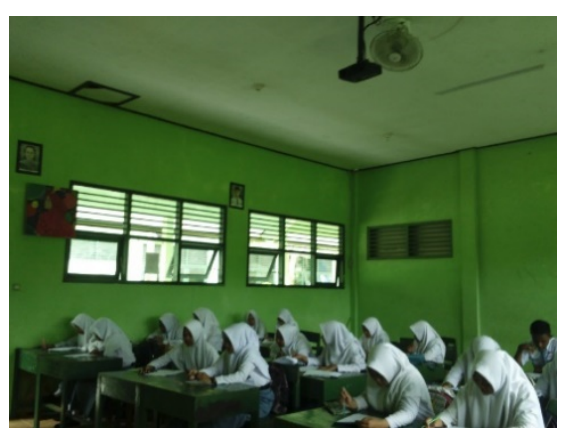

Gambar 1. Pembacaan Asmaul Husna Sebelum Pelajaran (Sumber : Dokumentasi Penulis, 2017)

Pengaruh globalisasi dan perkembangan IPTEK yang begitu deras, berdampak bagi masyarakat termasuk anak-anak, remaja dan orang tua, untuk itu harus disikapi dengan arif dan bijaksana, untuk menyikapinya dibutuhkan filter solihnya mental spriritual. Oleh karena itu, program keagamaan yang ditanamkan di sekolah sangat dibutuhkan guna menyeimbangkan perilaku dan pengetahuan anak. Kegiatan inti dalam pembelajaran meliputi :

\section{a. Eksplorasi}

Dalam kegiatan eksporasi, guru melibatkan peserta didik XI IIS 2 dalam mencari informasi menggunakan sumber belajar berupa LKS Sosiologi dan koran terkait masyarakat multikultural. Dalam kegiatan eksplorasi guru mendorong peserta didik untuk berpartisipasi aktif baik melalui pendapat dan menyampaikan informasi baru yang telah ditemukan dan di diskusikan oleh peserta didik terkait materi masyarakat multikultural. Selanjutnya Guru memberikan pertanyaan terkait kelompokkelompok dalam masyarakat dan salah satu peserta didik laki-laki menjawab. Pada kegiatan elaborasi, Guru memfasilitasi terjadinya interaksi antara peserta didik dengan Guru maupun peserta didik dengan peserta didik. Selanjutnya Guru memberikan penjelasan terkait pengertian masyarakat multikultural dan faktor yang mempengaruhi terbentuknya masyarakat multikultural. Guru menggunakan buku pegangan sosiologi dan menuliskan informasi baru di papan tulis. Ketika Guru menjelaskan, peserta didik menyimak Lembar Kerja Peserta didik dan menulis jika ada informasi baru yang tidak ada di LKS.

\section{b. Elaborasi}

Dalam kegiatan elaborasi, peserta didik mengerjakan "Ujian Penguasaan Materi" yang ada di buku pegangan Guru. Guru menuliskan soal di papan tulis dan peserta didik menjawab soal secara runtut. Selanjutnya, peserta didik mengumpulkan lembar jawab kepada Guru dan Guru memilih beberapa lembar jawab untuk melihat hasil pekerjaan peserta didik. Selanjutnya dilakukan pembahasan soal dan jawaban bersama-sama. Selama membahas soal, Guru menunjuk peserta didik untuk memberikan jawaban dan alasannya. Hal ini bertujuan untuk melatih peserta didik berpikir kritis dalam memecahkan masalah serta melatih keberanian peserta didik untuk belajar menyampaikan pendapatnya di depan umum, selanjutnya peserta didik dan guru membuat rangkuman secara bersama-sama. Dari sini dapat terlihat bahwa keaktifan siswa terbentuk karena proses penunjukkan oleh guru, tidak pada kebutuhan belajar dari peserta didik. Proses semacam ini merupakan upaya guru dalam membentuk sikap kritis pada peserta didik lewat keaktifan berargumentasi meskipun guru tidak banyak melakukan inovasi, baik dari aspek metode, model, dan teknik pembelajaran dalam kelas.

\section{c. Konfirmasi}

Dalam kegiatan konfirmasi, guru memberikan umpan balik terhadap apa yang dihasilkan peserta didik melalui pengalaman belajar, memberikan apresiasi terhadap kekuatan dan kelemahan hasil belajar, menambah informasi bagi peserta didik dan mendorong peserta didik menggunakan pengetahuan lebih lanjut dari sumber terpecarcaya untuk lebih menguatkan penguasaan kompetensi belajar.

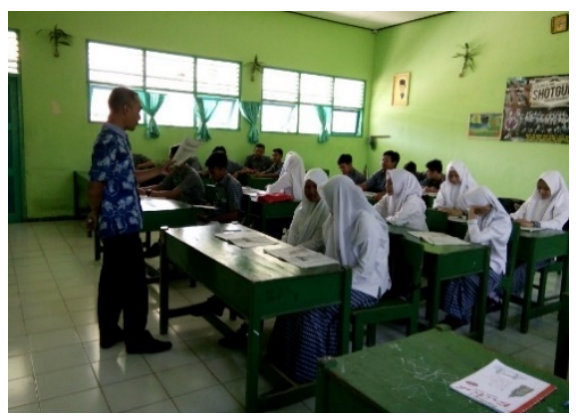

Gambar 2. Proses Tanya Jawab antara Guru dan Peserta didik

( Sumber : Dokumentasi Penulis, 2017) 
Pada kegiatan konfirmasi dalam pembelajaran masyarakat multikultural, peserta didik menyimpulkan dan menjelaskan tentang hal-hal yang belum diketahui seperti pengertian masyarakat multikutural dan faktor pembentuk masyarakat multicultural. Sedangkan guru berperan sebagai fasiitator dan narasumber serta memberikan konfirmasi melalui berbagai sumber seperti buku pegangan guru terhadap hasil eksplorasi dan elaborasi yang telah dilakukan oleh peserta didik. Kegiatan inti pada pembelajaran masyarakat multikultural membutuhkan waktu selama 110 menit mulai dari kegiatan eksplorasi, elaborasi dan konfirmasi.

\section{d. Kegiatan Akhir}

Pada kegiatan akhir, guru memberikan pertanyaan kepada seluruh peserta didik di kelas dan secara bersama-sama peserta didik menjawab pertanyaan yang diberikan oleh guru, selanjutnya peserta didik di beri tugas oleh guru untuk mengerjakan soal latihan di LKS Sosiologi pada halaman 56-58 yang akan dibahas pada pertemuan selanjutnya. Guru mengakhiri pertemuan dan memberikan salam.

Dari aspek praktik dan evaluasi pembelajaran matapelajaran Sosiologi di SMA Kedungreja pasca FDS, tidak banyak mengalami perubahan. Secara kualitas baik saat menjalankan dan pasca FDS tetap menggunakan model, teknik, dan metode pembelajaran dengan memperhatikan kompleksitas materi dan kondisi peserta didik. Bedanya hanya terletak pada variasi model pembelajaran dan lamanya jam pelajaran di sekolah. Pada saat pelaksanaan FDS, model yang digunakan lebih bervariasi, tetapi kondisi fisik dan psikis para para fasilitator dan peserta didik tidak memungkinkan terjadinya pembelajaran yang ideal. Sementara pasca FDS, model pembelajarannya kurang bervariatif, tetapi tidak mengesamping kualitas pembelajaran dengan berpedoman pada prinsip-prinsip pembelajaran pedagogik. Berbagai upaya tetap dilakukan oleh guru (Sosiologi) untuk memungkinkan proses pembelajaran yang ideal dengan menawarkan satu paket didaktif dalam pembelajaran dengan pendekatan ilmiah. Pun demikian dengan guru matapelajaran yang lain tetap melakukan berbagai upaya untuk menghasilkan proses dan hasil pembelajaran yang berkualitas.

\section{Dampak Sekolah Enam Hari Pasca Full Day School dalam Pembelajaran di SMA Negeri 1 Kedungreja}

Sekolah enam hari pasca full day school mulai dijalankan kembali pada awal tahun ajaran 2016/2017 sampai sekarang. Dalam praktiknya sekolah enam hari pasca full day school berdampak pada proses pembelajaran sosiologi dalam berbagai aspek di antaranya; Pertama, keaktifan belajar peserta didik. Keaktifan belajar adalah kegiatan atau kesibukan peserta didik dalam kegiatan belajar mengajar di sekolah maupun di luar sekolah yang menunjang keberhasilan belajar peserta didik. Terdapat beberapa aktifitas yang dilakukan peserta didik dalam kegiatan belajar yaitu mendengar, melihat, mencium, meraba, merasa, mengolah ide dan menyatakan pendapat. Belajar merupakan aktifitas yang berlangsung melalui proses, tentunya tidak terlepas dari pengaruh baik dari dalam individu yang mengalaminya. Pada penelitian pertama dan kedua yang telah dilakukan oleh penulis terkait proses pembelajaran Sosiologi pasca full day school di kelas XI IIS 2, penulis melihat terdapat keaktifan belajar peserta didik. Selain aktifitas mendengarkan, menulis, menyimak, dan mengolah ide, peserta didik juga mampu berpartisipasi dalam menyampaiakan pendapat mereka megenai pengertian masyarakat dan pengetian multikultural, selanjutnya salah satu peserta didik bernama Iham Hidayatulloh menyampaikan pertanyaan kepada guru seputar masyarakat multicultural. Kedua, Kinerja Guru.

Kinerja guru merupakan merupakan proses pembelajaran sebagai upaya mengembangkan kegiatan yang ada menjadi kegiatan yang lebih baik, sehingga tujuan pendidikan yang telah ditetapkan dicapai dengan baik melalui suatu kegiatan pembelajaran yang dilaksanakan oleh guru sesuai dengan target dan tujuan. Terdapat beberapa faktor yang memepengaruhi kinerja guru Sosiologi di SMA Negeri 1 Kedungreja yaitu faktor individu, psikologis dan faktor organisasi. Melalui observasi yang telah dilakukan penulis dalam pembelajaran sosiologi di kelas XI IIS 2, penulis mendapatkan data terkait kinerja guru sosiologi di SMA Negeri 1 Kedungreja berdasarkan perilaku dan sikap guru selama proses pembelajaran berlangsung. Guru Sosiologi di SMA Negeri 1 Kedungreja memiliki semangat mengajar yang tinggi. Hal ini berdasarkan indikator penilaian kinerja guru seperti guru yang selalu memotivasi peserta didik, guru menguasai materi, guru menggunakan sumber belajar yang relevan, guru dapat mengelolah kelas, guru dapat berinteraksi dengan peserta didik, guru memiliki gestur tubuh yang 
tegap, suara mengajar yang lantang, menguasai materi dan selalu responsif terhadap peserta didik. Dimulai dari awal hingga pembelajaran berakhir guru selalu memiliki perilaku dan sikap seperti di awal pembelajaran. Ketiga, nilai Akademik Peserta didik.

Nilai akademik peserta didik merupakan salah satu alat yang menjadi tolak ukur ketercapaian suatu tujuan pembelajaran yang dilihat berdasarkan kuantitas. Meskipun tidak selamanya nilai akademik dijadikan sebagai satusatunya patokan untuk melihat ketercapaian pembelajaran. Nilai akademik peserta didik di dapatkan melalui pre-test dan post-test yang diberikan oleg guru. Nilai tersebut bukanlah didapatkan dari salah satu aspek saja seperti aspek kognitif, melainkan juga didapatkan dari aspek afektif dan psikomotorik yang ketiganya akan di gabungkan dan menjadi satu nilai yaitu nilai akhir yang berupa angka maupun angka yang dikonversikan menjadi huruf. Nilai kriteria ketuntasan minimal atau KKM pada mata pelajaran sosiologi yaitu untuk kelas X memiliki KKM 70, kelas XI memiliki KKM 71 dan kelas XII memiliki KKM 73. Sebagaian besar peserta didik mendapatkan nilai yang meningkat ketika pembelajaran pasca full day school, nilai tersebut di atas nilai KKM dengan kriteria tuntas.

\section{Kendala dalam Proses Pembelajaran Sekolah Enam Hari pasca Full Day School}

Meskipun sekolah sudah menghentikan kebijakan full day school, dalam pelaksanaan pembelajaran sosiologi masih terdapat beberapa kendala yang dihadapi guru dan peserta didik, di antaranya: Pertama, ketersediaan Sumber Daya Manusia. Jumlah guru sosiologi yang terdapat di SMA Negeri 1 Kedungreja adalah satu orang saja yaitu Bapak Novrianto, Bapak Novrianto harus mengampu sebanyak 12 kelas per minggu. Keterbatasan jumlah guru sosiologi membuat Bapak Novrianto menjadi kerepotan karena selain harus mengajar seorang diri, beliau jug harus membuat perangkat pembelajaran dan mengoreksi ulangan sendiri, selain itu ketika beliau menjumpai kesulitan dalam materi sosiologi, beliau tidak memiliki teman untuk di ajakberdiskusi membahas permasalahan yang di hadapinya. Kedua, Sarana dan prasarana.

Peserta didik di SMA Negeri 1 Kedungreja dilarang membawa alat komunikasi berupa handphone atau smartphone oleh karena itu, jika ada pembelajaran yang bersumber dari internet, peserta didik memanfaatkan sarana dan prasarana sekolah yaitu dengan pergi ke laboratorium komputer untuk megakses internet, namun konektivitas jaringan internet sekolah dalam kondisi yang tidak stabil dan sering bermasalah. Ketiga, Kondisi ekonomi sosial peserta didik. Keterbatasan ekonomi sosial peserta didik menjadi salah satu penghambat pembelajaran, yaitu kepemilikan buku paket. Selain LKS yang digunakan peserta didik dalam mengakses sumber belajar, buku paket juga sangat diperlukan untuk menunjang pembelajaran dan menambah wawasan pengetahuan karena di dalam buku paket terdapat materi yang lebih lengkap. LKS berisi materi sekilas saja dan berisi soal-soal latihan. Tidak semua peserta didik mampu membeli buku paket, sehingga pada saat pembelajaran peserta didik harus berbagi dengan temannya yang memiliki buku. Hal ini membuat pembelajaran menjadi kurang efektif karena peserta didik yang bergabung dengan teman yang memiliki buku paket akan mengobrol di luar materi pelajaran.

\section{Tanggapan terhadap Praktik dan Evaluasi pembelajaran pasca FDS di SMA N 1 Kedungreja}

Berikut merupakan beberapa tanggapan dari hasil praktik dan sebagai evaluasi pembelajaran pasca FDS di SMA N 1 Kedungreja, yaitu:

\section{a. Tanggapan Guru}

Guru merupakan pihak yang terlibat langsung dalam pelaksanaan kebijakan sekolah enam hari, khususnya dalam proses pembelajaran di kelas. Sebagian guru di SMA negeri 1 Kedungreja setuju dengan kebijakan sekolah enam hari per minggu dengan beberapa alasan di antaranya, yaitu sekolah enam hari lebih efektif, dalam proses pembelajaran peserta didik lebih responsif, guru tidak terforsir dan kelelahan serta guru dapat pulang lebih awal dan memiliki waktu untuk keluarga lebih banyak.

Ibu Yeti adalah salah satu guru ekonomi yang mengampu pelajaran ekonomi pada kelas X IIS dan lintas minat pada kelas MIA. Beliau setuju dengan keputusan yang diambil sekolah terkait kebijakan sekolah enam hari pasca full day school karena pada saat pelaksanaan sekolah lima hari beliau merasa kesulitan membagi waktu dengan keluarga. Di samping itu, jam mengajar yang terlalu banyak ketika full day school membuat beliau kelelahan dan jenuh. Selain mengajar, beliau juga memiliki tugas di 
luar jam sekolah seperti membina kegiatan ekstrakulikuler pramuka dan OSN bidang ekonomi. Beliau bengatakan bahwa terdapat perbedaan antara full day school dan sekolah enam hari. Perbedaan tersebut terdapat pada respon peserta didik. Peserta didik lebih antusias dan lebih semangat ketika sekolah enam hari hal ini dilihat berdasarkan keaktifan belajar peserta didik.

Menurut Roger (1938) salah satu hambatan dalam difusi inovasi adalah telah berada pada wilayah zona nyaman. Penerima inovasi yang berada pada zona nyaman cenderung akan merasa lebih berat untuk menerima penyebaran inovasi. Sebelum menjalankan full day school, SMA Negeri 1 Kedungreja menerapkan kebijakan sekolah enam hari dari awal sekolah berdiri, yakni pada tahun 1988 hingga tahun 2015. Guru dan peserta didik di sekolah tersebut sudah terbiasa dengan sekolah enam hari yang memiliki jadwal pelajaran lebih sedikit dan waktu pulang lebih awal daripada full day school. Ketika Gubernur Jawa Tengah mengeluarkan peraturan nomor 420/006752/2015 tentang penyelenggaraan kegiatan pendidikan dan sekolah ditunjuk untuk mengimplementasikan kebijakan tersebut, maka sekolah belum memiliki persiapan yang matang dari berbagai aspek serta guru dan peserta didik sudah terbiasa dengan sekolah enam hari, sehingga sekolah mengalami kendala dalam pelaksaaan full day school. Konsekuensinya sekolah memutuskan untuk menghentikan full day school dan kembali pada kebijakan sekolah enam hari. Keputusan sekolah untuk kembali pada kebijakan lama yaitu sekolah enam hari, merupakan sebuah bentuk kegagalan dari full day school itu sendiri.

\section{b.Tanggapan Peserta Didik}

Peserta didik di SMA Negeri 1 Kedungreja sebagian besar setuju dengan kebijakan sekolah enam hari pasca full day school. Peserta didik memiliki beberapa alasan mengapa lebih memilih sekolah enam hari pasca full day school yaitu; durasi waktu sekolah enam hari lebih singkat dari full day school, peserta didik dapat pulang lebih awal, peserta didik dapat membantu orang tua di rumah dan mendapatkan nilai akademik yang lebih bagus.

Erik Sujatmiko merupakan peserta didik kelas XI MIA 2 sekaligus sebagai ketua OSIS di SMA Negeri 1 Kedungreja. Selain berorgaanisasi, peserta didik tersebut juga memiliki prestasi akademik yang bagus, dan selalu menjadi juara kelas. Erik setuju dengan kebijakan sekolah enam hari pasca full day school, karena pulangnya tidak terlalu sore sehingga sampai rumah bisa beristirahat dan membantu orang tua. Selain itu,
Erik dapat belajar dan mengerjakan tugas sekolah dengan maksimal.

\section{c. Tanggapan Orang Tua Peserta Didik}

Orang tua peserta didik ikut terlibat dalam proses pengambilan keputusan sekolah terkait penghentian kebijakan full day school di SMA Negeri 1 Kedungreja melalui angket yang di berikan kepada ornag tua peserta didik, hasilnya, sebanyak $75 \%$ orang tua peserta didik setuju dan $25 \%$ orang tua tidak setuju dengan kebijakan tersebut. Orang tua peserta didik memiliki berbagai alasan mengapa mereka menyetujui sekolah enam hari pasca full day school di antaranya; full day school membuat anak menjadi tertekan dan kelelahan karena seharian berada di sekolah, full day school membuat anak-anak tidak bisa mengikuti madrasah sore hari sehingga anak tidak bisa menuntut ilmu agama, full day school membuat orang tua khawatir karena anak pulang terlalu sore, dan full day school membuat nilai akademik anak menjadi menurun.

Bapak Darsim (51 Tahun) adalah salah satu orang tua peserta didik yang setuju dengan kebijakan sekolah enam hari pasca full day school. Beliau merupakan orang tua dari siswi yang bernama Ari Rahmawati kelas XI IMIA 1. Beliau setuju dengan kebijakan penghentian full day school dan kembali pada sekolah enam hari karena beliau merasa kasihan dengan anaknya yang selalu pulang sekolah pada waktu menjelang maghrib. Jarak sekolah sekitar $9 \mathrm{~km}$ dari rumah membuat siswi tersebut harus berangkat pukul 06.00 dan pulang sampai di rumah pada pukul 17.30 .

Tanggapan orang tua peserta didik yang tidak setuju dengan penghentian full day school salah satunya adalah Ibu Sugiyah (37 Tahun) merupakan orang tua dari siswi Siti Rofidah XI MIA 1. Ibu sugiyah bekerja sebagai pedagang makanan di Pasar Setuan. Beliau salah satu orang tua yang tidak setuju jika kebijakan full day school dihentikan karena hari libur selama dua hari dapat digunakan anaknya untuk membantunya berjualan di pasar setuan. Hari sabtu merupakan hari pasaran di Pasar Setuan, sehingga ketika hari Sabtu, maka pembeli akan lebih ramai dari biasanya dan Siti Rofidah selalu membantu ibunya untuk melayani pembeli. Ibu Sugiyah juga lebih senang jika anaknya pulang 
sore karena anak sudah pasti melakukan kegiatan yang positif jika berada di sekolah. selain itu, beliau dan suaminya tidak berada di rumah dari pagi hingga sore sehingga tidak bisa mengontrol aktivitas anaknya dan lebih memercayakan sekolah sebagai tempat yang lebih tepat.

\section{d. Tanggapan Kepala Sekolah jika Full Day School Resmi Dijalankan oleh Pemerintah}

Kepala SMA Negeri 1 Kedungreja mengatakan bahwa pihak sekolah akan menyelenggarakan kembali kebijakan full day school, namun melalui beberapa tahap. Sekolah membutuhkan persiapan yang matang untuk menyelenggarakan kebijakan full day school, seperti yang disampaikan oleh Bapak Kusworo selaku kepala SMA Negeri 1 Kedungreja:

" iya mbak, jadi karena full day school ini sudah resmi dijalankan di seluruh Indonesia, maka sekolah memiliki rencana untuk kembali menjalankan program full day school, tapi tidak secara langsung saat ini juga karena sekolah membutuhkan persiapan yang benar-benar matang seperti melengkapi sarpras yang masih kurang, persiapan bagi guru dan peserta didik, sosialisasi ulang kepada orang tua peserta didik dan perencanaan program yang akan dijalankan ketika full day school.

Adapun persiapan yang dilakukan oleh sekolah dalam mengimplementasikan kebijakan full day school yaitu: pertama, pemenuhan saran dan prasarana. Kedua, persiapan sumber daya manusia atau tenaga pendidik. Ketiga, persiapan peserta didik. Keempat, sosialisasi kepada orang tua peserta didik. Dan kelima, managemen sekolah.

\section{KESIMPULAN}

Berdasarkan hasil pembahasan di atas terdapat beberapa poin penting dalam kebijakan kembalinya sekolah dalam menerapkan kebijakan enah ari sekolah pasca FDS. Adapun alasan SMA Negeri 1 Kedungreja kembali pada kebijakan enam hari sekolah pasca full day school karena dalam pelaksanaan full day school di SMA Negeri 1 Kedungreja, sekolah mengalami kendala dalam beberapa aspek seperti aspek psikologis, aspek sarana dan prasarana, aspek kebijakan sekolah, aspek guru dan peserta didik, aspek nilai akademik peserta didik dan aspek kondisi ekonomi sosial peserta didik. Kendala di atas merupakan kendala yang dihadapi oleh SMA Negeri 1 Kedungreja dalam pelaksanaan full day school.

Proses pelaksanaan pembelajaran dalam sekolah enam hari pasca full day school di SMA Negeri 1 Kedungreja tidak jauh berbeda dengan pembelajaran ketika full day school baik dilihat dari model dan metode yang digunakan. Meskipun sekolah sudah tidak menjalankan full day school dan kembali pada kebijakan sekolah enam hari, terdapat beberapa kendala yang dihadapi guru dan peserta didik dalam pembelajaran sosiologi di kelas seperti kurangnya guru sosiologi, sarana dan prasarana yang belum lengkap dan kepemilikan buku paket bagi peserta didik. Selain itu sekolah enam hari berdampak pada keaktifan belajar peserta didik, kinerja guru dan nilai akademik peserta didik.

Guru, peserta didik, dan orang tua peserta didik memberikan tanggapan yang beragam terkait pelaksanaan sekolah enam hari pasca full day school. Guru dan peserta didik menyambut baik akan kebijakan tersebut, sedangkan orang tua peserta didik ada yang setuju dan ada pula yang tidak setuju dengan masing-masing alasan. Kepala sekolah memberikan tanggangapan jika full day school resmi dilaksanakan, maka sekolah akan kembali menjalankan kebijakan tersebut dengan melalui beberapa tahap pesiapan diantaranya pemenuhan sarana dan prasarana, persiapan sumber daya manusia atau tenaga pendidik, persiapan bagi peserta didik, sosialisasi terhadap orang tua peserta didik dan persiapan dalam managemen sekolah.

\section{REFERENSI}

Arikunto, Suharsimi \& Cepi Safruddin. 2014. Evaluasi Program Pendidikan. Jakarta: Bumi Aksara.

Arioka, Ni Wayan Widayanti. 2018. Pro Kontra Wacana Full Day School. Dalam Jurnal Studi Kultural. Volume 3. No.1. Hal 1-5.

Arsyadana, Addin (2010), Penerapan Sistem Full Day School Sebagai Upaya Untuk Meningkatkan Kualitas Pendidikan Di Mi Al-Qamar Nganjuk. Skripsi. UIN Malang 
Clark, P. 2004. "Recent Research on All-Day Kindengarten". ERIC Journal. Vol. 01. No: 3 .

Hastuti Afsya Oktaviani dan Nurul Fatimah. 2015. Implementasi Pendidikan Karakter Religius dalam Pembelajaran Sosiologi. Jurnal Komunitas. Vol 4 No. 2 Hal. 121130.

Holm Lars. 2014. Parental Perspectives on Danish Full-day School For Ethnic Minority Students. International Journal about Parent in Education Vol 8. No 1. Page: 23-33

Insriani, Hezti. 2011. Pembelajaran Sosiologi yang menggugah Minat Peserta didik. Jurnal Komunitas. Vol 3 No 1. Hal 92102.

Lamadirisi Maryam. 2012. Tingkat Afeksi Peserta didik dalam Mengikuti Pembelajaran Sosiologi dengan Contextual Teaching and Learning. Jurnal Komunitas. Vol 4 No. 1 Hal 205-215.
Refliandra,Rina. 2014. Perbedaan Tingkat Stress antara Peserta didik Sekolah Dasar yang Bersistem Full Day dan Half Day. Jurnal Proyeksi. Vol 6 No 1 Hal 40-44.

Yusuf Amin, 2013. Difusi Inovasi Pendidikan. Semarang : Deepublish.

Sofanudin, Ali. 2017. Dalam http://jateng.tribunnews.com/2017/06/15/ mengulas-kebijakan-full-day-school-plus$\underline{\text { minus-lima-hari-sekolah?page }=\text { all. }}$.

Sugiyono. 2013. Metode Penelitian Pendidikan. Bandung: Alfabeta.

Wulandari, dkk. 2018. Analisis Implementasi Full Day School Sebagai Upaya Pembentukan Karakter Peserta didik di SD muhammadiyah 4 kota malang. Dalam Jurnal Pemikiran dan Pengembangan SD. Volume 6, Nomor 1, April 2018. Halaman 65-74. 